(c) 1980. The Genetical Society of Great Britain

\title{
NUCLEOLUS-ORGANISER REGIONS IN FAMILIAL EXTRA METACENTRIC HUMAN CHROMOSOMES
}

\author{
A.-M. SALMASI*, S. MALCOLM†, T. ELLIOTT †, R. WILLIAMSON*, \\ and M. A. FERGUSON-SMITH† \\ * Department of Biochemistry, St Mary's Hospital Medical School, Paddington, London W2 1PG; \\ +Department of Biochemistry, Queen Elizabeth College, Campden Hill Road, London W8 7AM; \\ ¡Department of Medical Genetics, Royal Hospital for Sick Children, Yorkhill, Glasgow G3 8Sj
}

Received 19.iv.79

\section{SUMmary}

A small extra bisatellited metacentric chromosome has been found in two unrelated normal females and their foetuses. The presence of two nucleolusorganiser regions (NOR's) on these chromosomes was defined by in situ hybridisation of $28 \mathrm{~S}$ and $18 \mathrm{~S}$ ribosomal genes, silver staining and the observation of satellite association. C-banding strongly suggests that they are also dicentric.

The characteristic silver-staining and the high frequency of involvement of the marker chromosome in satellite association indicates the functional activity of the nucleolar-organiser regions on both extra chromosomes. In both cases, it seems likely that the extra chromosome has arisen by a centric fusion translocation and is not an isochromosome, because the chromosome arms show differences in length, satellite size, Ag-staining and participation in satellite association.

\section{INTRODUGTION}

THE occurrence of a small extra metacentric chromosome has often been reported in humans (Ilbery et al., 1961). Surveys show that such a marker chromosome can occur in phenotypically normal individuals and their families (Walzer et al., 1969; Friedrich and Nielsen, 1974; Nielsen, 1974; Nielsen and Rasmussen, 1975) or may be associated with a wide range of clinical abnormalities (Bain, 1973). Their unexpected occurrence in the course of pre-natal diagnosis and the implications of this finding have recently been discussed by Bernstein et al. (1978).

The origin of these extra chromosomes is difficult to determine because of their small size. However, the identification of the marker chromosome as a derivative of at least one of the acrocentric chromosomes is suggested by the presence of satellites on one or both arms. Staining methods specific for the short arms of each of the five pairs of acrocentric chromosomes would be helpful in identifying which had contributed to the marker, but only chromosome 15 appears to have such a specific test at present (Schreck et al., 1977); this involves a characteristic reaction to anti-5-methylcytidine.

In this paper we describe studies of the nucleolus-organiser regions in two extra bisatellited metacentric chromosomes found unexpectedly during prenatal diagnosis in different families. The technique of in situ hybridisation, using a radioactive probe specific for $28 \mathrm{~S}$ and $18 \mathrm{~S}$ ribosomal genes (rDNA), has been used to quantitate the relative amount of rDNA (Malcolm et al., 1977), and the silver staining method of Bloom and Goodpasture (1976) 
used to indicate the functional activity of the NOR's (Miller et al., 1976a,b). The frequency of satellite association was used as a measure of the involvement of the marker chromosome in the interphase nucleolus. These studies have provided additional information concerning the origin and behaviour of extra metacentric chromosomes.

\section{CASe Reports}

(i) Case $A$

Mrs A, a 26-year-old patient, attended the Genetic Counselling Clinic at the Royal Hospital for Sick Children, Glasgow, in 1975, during the first trimester of her second pregnancy. Amniocentesis was performed to exclude Niemann-Pick disease in the foetus. Her first baby, a girl, died during infancy of this disease. Chromosome analysis of the amniotic fluid cells was also carried out as a routine procedure. This revealed an extra small bisatellited metacentric chromosome in all cells. Parental blood was immediately taken for chromosome analysis and this showed an identical finding in the normal mother. It was concluded that the extra chromosome was of no clinical significance and the pregnancy was allowed to continue as assay of cultured amniotic fluid cells also revealed normal sphingomyelinase activity. A normal female baby was born later who continues to develop normally.

\section{(ii) Case D}

A sample of amniotic fluid from a 35-year-old patient, Mrs D, was sent in 1975 to the Medical Genetics Department, Royal Hospital for Sick Children, Glasgow, for analysis. The indication for amniocentesis was the previous birth of a child with spina bifida in her third pregnancy. Routine chromosome analysis was carried out on the amniotic fluid cells with similar findings to Case A. Again, chromosome analysis of parental lymphocytes showed that the mother also had the extra metacentric. The pregnancy was allowed to continue to the delivery of a normal baby with normal development up to the present.

\section{Methods}

Chromosome preparations were made from cultures of amniotic cells and peripheral blood cultures, stained by G- and G-banding and analysed as described by Ferguson-Smith (1974). In situ hybridisation was carried out as described previously (Malcolm et al., 1977). The probe used was a bacterial plasmid PMB9 containing Xenopus laevis 28S and 18S rRNA genes. The plasmid DNA was labelled to a specific activity of $10^{7} \mathrm{dpm} / \mu \mathrm{g}$ with tritium by " nick-translation". Chromosome preparations were silverstained using the Ag-I method of Bloom and Goodpasture (1976) and either counter-stained in Giemsa ( 2 per cent in 0.01 м Sorensen's phosphate buffer $p \mathrm{H} \mathrm{7.0)}$ or Trypsin-Giemsa banded (Seabright, 1971).

\section{Results}

Chromosome analysis of mothers and foetuses in both cases show a $47, \mathrm{XX}+$ mar karyotype. The marker chromosome in each is a small metacentric, bisatellited chromosome. The length of the marker chromosome is 
equivalent to 1.35 per cent of the total genome length in Case A, and 1.22 per cent in Case D. In both, the short arms and satellites fluoresce dully by Q-banding. In Case A, each arm is similar in length but one satellite is more readily distinguished than the other. In Case D, satellites are prominent in both arms although one appears larger than the other. C-banding demonstrates the presence of a heterochromatic region proximal to the secondary constriction in each arm (fig. 2) consistent with the interpretation that each metacentric is dicentric. Grain counts from in situ hybridisation of the 28S and 18S gene probe to the mother's chromosomes are shown in table 1. The D, G and marker chromosomes are clearly labelled above background and the marker chromosome is nearly four times more heavily

TABLE 1

In situ hybridisation. Distribution of grains over the acrocentric chromosomes and the marker chromosomes compared to background

$\begin{array}{ccc}\text { Average grains per short arm region of D chromosomes } & \text { Case A* } & \text { Case D } † \\ \text { Average grains per short arm region of G chromosomes } & 1 & 1.4 \\ \text { Average grains per marker chromosome } & 3.8 & 1.05 \\ \text { Background grains per unit length (1\% genome) } & 0.04 & 3.8 \\ \qquad \text { * Case A }=8 \text { cells scored. } & \\ \qquad \text { Case D }=18 \text { cells scored. }\end{array}$

labelled than the short arm and satellite regions of the average $\mathrm{D}$ or $\mathrm{G}$ group chromosomes. The D group chromosomes in Case D are approximately 40 per cent more heavily labelled than the G group, but in Case A the labelling is roughly equivalent. The marker chromosome is labelled in 93 per cent of cells in Case D. It is not possible to distinguish between the two ends of the marker chromosomes after in situ hybridisation but grains are distributed over both satellite regions in 50 per cent of the cells in Case A, and 30 per cent in Case D (see fig. 2). This strongly suggests that nucleolusorganiser regions are present on both ends of the extra chromosomes. This is confirmed by the silver-staining procedure. Silver-staining is observed on both ends of the marker chromosome in all 20 cells scored in Case A, and all 22 in Case D (fig. 2). The intensity of the stain appears to be the same on both ends of the chromosome in Case A, but one end shows heavier staining in Case $\mathrm{D}$ (figs. 1 and 2).

In Case A, three D and two G chromosomes stain by the Ag-I method in four of five cells scored, and four D and two $G$ in the remaining cell. These were identified by Trypsin banding as both 13's and 14's, one 21 and one 22 . In Case D, four D and 3 G's are silver-stained in eight out of twelve cells and five $D$ and three $G$ in the remaining four. Trypsin banding showed these to be both 13's, one 14 and 15, both 21's and one 22 (fig. 1).

The results for satellite associations are shown in table 2. Fifty cells were scored in Case D and 30 cells in Case A. The total number of times a chromosome of each group was involved in a satellite association was scored and the result normalised to allow for the fact that there were six NOR's in the D group, four in the G group and two NOR's on the marker chromosome. In both cases the marker chromosome associates more than average. In Case $\mathrm{D}$, the increase of marker over $\mathrm{G}$ group chromosomes is most 
TABLE 2

Frequency of satellite associations of the marker chromosome compared to those for other acrocentric chromosomes

Satellite associations/NOR for Marker chromosomes Satellite associations/NOR for D group chromosomes Satellite associations/NOR for G group chromosomes

$\begin{array}{cc}\text { Case } \mathrm{A}^{*} & \text { Case } \mathrm{D} \dagger \\ 12 \cdot 0 & 23 \cdot 0 \\ 7 \cdot 2 & 21 \cdot 5 \\ 9 \cdot 25 & 9 \cdot 75\end{array}$

* Case $\mathrm{A}=30$ cells scored.

$\dagger$ Case $\mathrm{D}=50$ cells scored.

marked. In 20 cells in Case D, which had also been silver-stained, it is possible to distinguish between the ends. It was found that 80 per cent of the associations involving the marker chromosome were with the more heavily stained region.

\section{Discussion}

The conclusion from cytological observations that the marker chromosomes were derivatives of acrocentric chromosomes was confirmed by in situ hybridisation, which showed that $28 \mathrm{~S}$ and $18 \mathrm{~S}$ genes were present in both ends of the marker. Grain counts showed that the marker chromosome introduced an extra dose of ribosomal genes of 40 per cent (Case A) and 30 per cent (Case D), without apparent phenotypic effect.

Studies on rodent/man somatic cell hybrids have shown that only the NOR's of the species producing rRNA are stained by the Ag technique (Miller et al., 1977), and it has been assumed that this is a stain for active NOR's. Satellite association has also been considered as a measure of activity in production of rRNA as it is thought to involve those acrocentric chromosomes whose NOR's were involved in nucleolus formation in the previous interphase. By these criteria, the marker chromosome is active in ribosomal RNA synthesis at both NOR's.

At present there are conflicting results as to whether the frequency of satellite association is correlated to the number of rRNA genes present or to some other unknown factor (Evans et al., 1974; Henderson and Atwood, 1976; Warburton et al., 1976). Miller et al. (1977) have shown a strong correlation between the amount of silver stain and frequency of participation in association. In the cases reported here, the marker chromosome carried an above-average number of $18 \mathrm{~S}$ and $28 \mathrm{~S}$ ribosomal genes and was involved more often than average in satellite associations. This was particularly marked in Case D, where the end staining more heavily with silver was involved in 80 per cent of the associations of the chromosome. It was not possible to correlate this with rDNA content as the two arms of the marker chromosome could not be distinguished following in situ hybridisation. It has been suggested that participation of acrocentric chromosomes in satellite associations may predispose them to breakage and translocation (FergusonSmith and Handmaker, 1961), and it is noteworthy that at least one of the nucleolus-organiser regions in each of these marker chromosomes are particularly active in satellite associations. This may be an important factor in ensuring the transmission of the extra metacentric from one generation to the next. 
Plate I

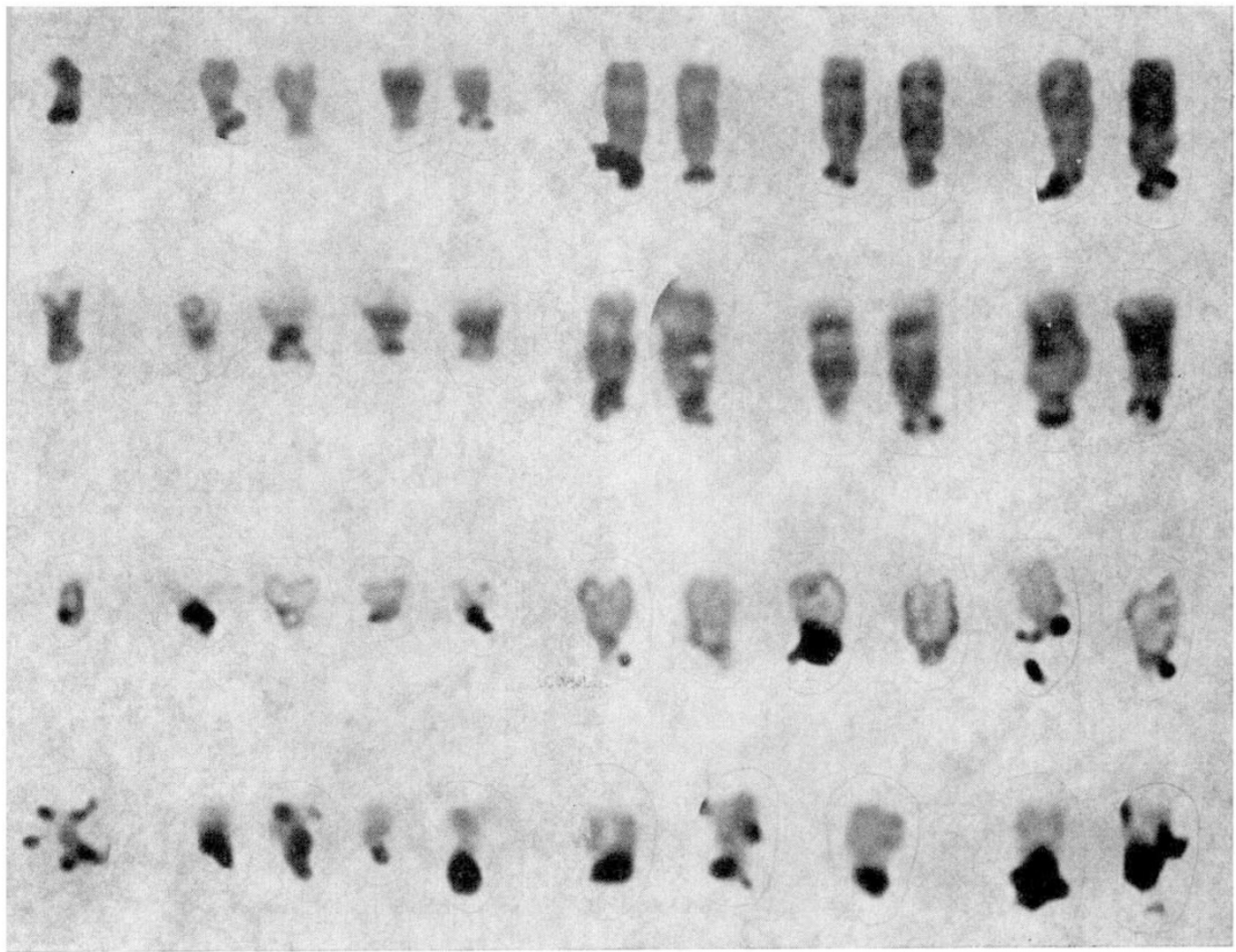

Fig. 1.-In situ hybridisation preparations (top two rows) and Ag-trypsin banding (bottom two rows) of the chromosomes containing nucleolar organisers in Cases A and D. 
Plate II

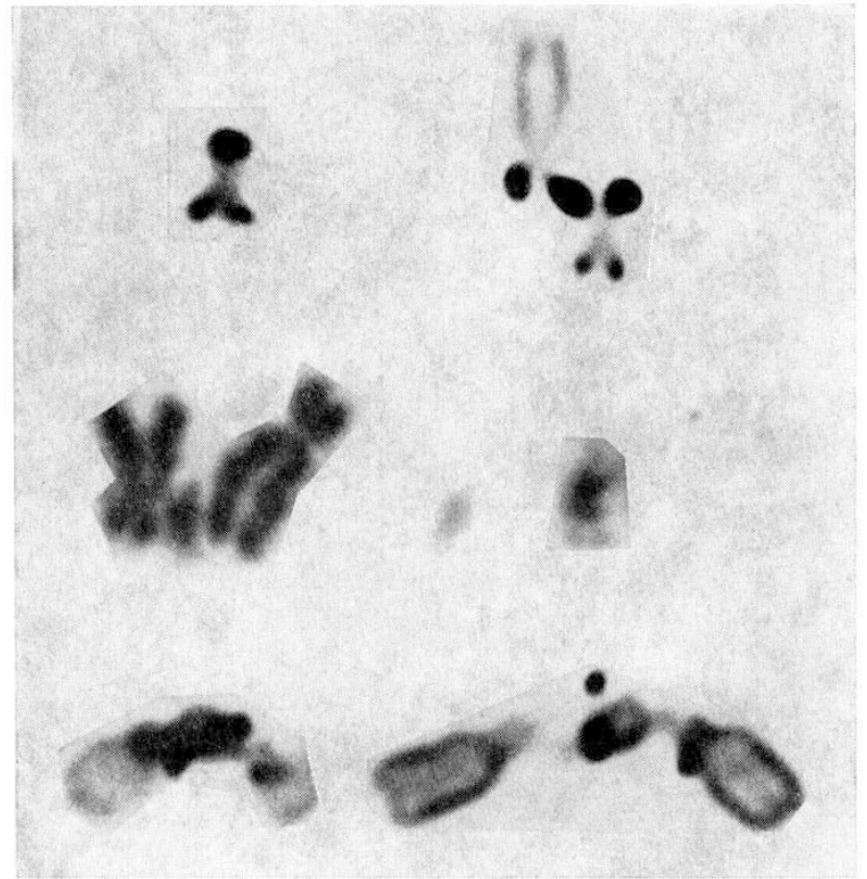

FIG. 2. - Examples of the extra metacentric chromosomes in Cases A and D using silver staining (top row), C-banding (middle row) and in situ hybridisation (bottom row). 
It has not been possible to determine from which of the acrocentric chromosomes the extra metacentrics have been derived. In cases such as these where the marker has been inherited, possibly through several generations, comparisons of the properties of the NOR's with those carried by the parent's chromosomes will not be informative, as the chromosomes giving rise to the marker chromosome may have been lost several generations previously due to normal meiotic segregation. However, certain conclusions can be drawn about the mechanisms of origin of the extra metacentrics from our findings. The two main possibilities for the origin of the aberration are isochromosome formation and centric fusion translocation. Both resulting aberrations can be dicentric, the former as a result of isochromatid breakage and fusion in the proximal part of the long arm of an acrocentric chromosome. However, isochromosome formation appears to be unlikely in either case as at least one technique demonstrates differences between the arms of the extra metacentric chromosomes. In case A, the major difference appears to be in the satellites, only one of which is readily distinguished in the majority of cells; no differences are observed in $\mathrm{Ag}$ staining, in situ hybridisation or satellite association. In Case D, the two arms are more asymmetrical in length, and one consistently shows heavier Ag staining with more frequent involvement in satellite association.

\section{REFERENCES}

BaIN, A. D. 1973. In Textbook of Paediatrics, ist Ed., ed. Forfar and Arneil. Churchill Livingstone.

BERNSTEIN, R., HAKIM, C., HARDWICK, B., AND NURSE, G. T. 1978. Significance of detection of extra metacentric microchromosome in amniotic cell culture. 7. Med. Genet., 15, 136-142.

BLOOM, S. E., AND GOODPASTURE, C. 1976. An improved technique for selective silver staining of nucleolar regions in human chromosomes. Hum. Genet., 34, 199-206.

EVANS, H. J., BUCKLAND, R. A., AND PARDUE, M. L. 1974. Location of the genes coding for $18 \mathrm{~S}$ and 28S ribosomal RNA in the human genome. Chromosoma, 48, 405-426.

FERGUSON-SMITH, M. A. 1974. Techniques of liuman chromosome analysis. La Ricerca Clin. Lab., 4, 297-335.

FERGUSON-SMITH, M. A. AND HANDMAKER, s. D. 1961. Observations on the satellited human chromosomes. Lancet, 1, 638-640.

FRIEDRICH, U., AND NIELSEN, J. 1974. Bisatellited extra small metacentric chromosome in new-borns. Clin. Genet., 6, 23-31.

HENDERSON, A. S., AND ATWOOD, K. c. 1976. Satellite association frequency and rDNA content of a double satellited chromosome. Hum. Genet., 31, 113-115.

ILBERY, P. L. T., LEE, C. W. E., AND WINN, S. M. 1961. Incomplete trisomy in a mongoloid child exhibiting minimal stigma. Med. F. of Australia, 48, 182-184.

MALCOLM, s., WILLIAMSON, R., BOYD, E., AND FERGUSON-SMTTH, M. A. 1977. A comparison of in situ hybridisation techniques for gene localisation. Cytogenet. Cell Genet., 19, 256-261.

MILLER, D. A., DEV, v. G., TANTRAVAHI, R., AND MILLER, o. J. 1976a. Suppression of a human nucleolus organiser activity in mouse human somatic hybrid cells. Exp. Cell. Res., 101, 235-243.

Miller, O. J., MilleR, D. A., DeV, v. G., TANTRAVAhi, R., AND GRoce, C. M. 1976 $b$. Expression of a human and suppression of mouse nucleolus organiser activity and mouse human somatic cell hybrids. Proc. Natl. Acad. Sci. U.S.A., 73, 4531-4535.

MILLER, D. A., TANTRAVAhI, R., DEV, v. G., AND MilleR, O. J. 1977. Frequency of satellite association of human chromosomes is correlated with amount of $\mathrm{Ag}$ staining of the nucleolar organiser regions. Am. F. Hum. Genet., 29, 490-502.

NIELSEN, J. 1974. Chromosome examination of new-born children. Purpose and ethical aspects. Humangenetik, 26, 215.

NIELSEN, J., AND RASMUSSEN, K. 1975. Extra marker chromosome in new-born children. Hereditas, 81, 221-224. 
SEABRIGHT, M. 1971. The use of proteolytic enzymes for the mapping of structural rearrangements in the chromosomes of men. Chromosoma, 36, 204.

SGHRECK, R. R., BREG, W. R., ERLANGER, B. F., AND MILLER, O. J. 1977. Preferential derivation of abnormal human $\mathrm{G}$ group like chromosomes from chromosome 15. Hum. Genet., 36 , $1-12$.

WAlzer, s., Breau, G., AND Gerald, P. s. 1969. A chromosome survey of 2,400 normal newborn infants. 7. Paediat., 74, 438-448.

WARBURTON, D., ATWOOD, K. C., AND HENDERSON, A. s. 1976. Variation in the number of genes for RNA among human acrocentric chromosomes: correlation with frequency of satellite association. Cytogenet. Cell Genet., 17, 221-230. 